\title{
Peripheral T follicular helper cells from H1N1/09 vaccine nonresponders fail to induce antigen-specific antibody production in vitro
}

\author{
A Parmigiani, S Pallikkuth, SY Silva, M Fischl, R Pahwa, S Pahwa \\ From AIDS Vaccine 2012 \\ Boston, MA, USA. 9-12 September 2012
}

\section{Background}

Mechanisms underlying poor $\mathrm{Ab}$ responses to vaccines in well controlled HIV infected patients are not fully understood. In this study we have examined the role of a novel subset, the peripheral $\mathrm{T}$ follicular helper cells (pTFH) in Ab production.

\section{Methods}

The study was conducted in cryopreserved cells of 16 HIVinfected, ART-treated individuals and 8 healthy donors (HD) who had been given a single dose of H1N1/09 influenza vaccine in 2009. Only 8 of the 16 patients and all HD had a flu-Ab response at 4 wks post vaccination. Vaccine responder (VR) and non responder (VNR) patients were equivalent in mean age, viral load, CD4 and CD8 $\mathrm{T}$ and B cells. B (CD20+) and TFH (CD3+ CD4+ CD45RACXCR5+) cells were purified by cell sorting on a FACS ARIA and co-cultured. IgG levels in culture supernatants were determined by ELISA. B and T cell phenotypic analysis was performed by multicolor flow cytometry. Differences between groups were analyzed by Student $\mathrm{t}$-test or the 2-sample Wilcoxon rank-sum (Mann-Whitney) test.

\section{Results}

Frequency of pTFH was equivalent in HIV+ patients and HD before vaccination. pTFH cells underwent significant expansion at wk4 compared to baseline in VR patients $(\mathrm{p}=$ $0.003)$ and HD $(p=0.001)$ with increased frequency of Ki67+ cells. In VR, H1N1-specific IgG production was evident in CD4+ CXCR5+/B cell co-cultures but not in CD4 + CXCR5-/B cell co-cultures $[\mathrm{HIV}+\mathrm{n}=3 ; \mathrm{p}=0.043]$ and [HD $\mathrm{n}=3 ; \mathrm{p}=0.014]$, concurrently with increase in

University of Miami, Miami, FL, USA

(C) 2012 Parmigiani et al; licensee BioMed Central Ltd. This is an Open Access article distributed under the terms of the Creative Commons Attribution License (http://creativecommons.org/licenses/by/2.0), which permits unrestricted use, distribution, and reproduction in any medium, provided the original work is properly cited. frequencies of plasmablasts. These changes were not seen in vaccine nonresponders.

\section{Conclusion}

pTFH cells promote antigen-specific Ab production by $\mathrm{B}$ cells in vitro. Although their relationship to lymph node germinal center TFH has not been clarified, analysis of pTFH function represents a novel and easily accessible surrogate marker for vaccine responsiveness in stable $\mathrm{HIV}$ infected patients with equivalent CD4 T cells.

Published: 13 September 2012

doi:10.1186/1742-4690-9-S2-P277

Cite this article as: Parmigiani et al:: Peripheral T follicular helper cells from $\mathrm{H} 1 \mathrm{~N} 1 / 09$ vaccine nonresponders fail to induce antigen-specific antibody production in vitro. Retrovirology 2012 9(Suppl 2):P277.

Submit your next manuscript to BioMed Central and take full advantage of:

- Convenient online submission

- Thorough peer review

- No space constraints or color figure charges

- Immediate publication on acceptance

- Inclusion in PubMed, CAS, Scopus and Google Scholar

- Research which is freely available for redistribution \\ () Biomed Central}

